\title{
Development of the agricultural sector in the Republic of Tatarstan
}

\author{
Nail Asadullin*, Fayaz Avkhadiev, Ilgizar Gainutdinov, and Liliya Mikhailova \\ Kazan State Agrarian University, Kazan, 420015, Russia
}

\begin{abstract}
The article describes the current level of agricultural development in the Republic of Tatarstan. The current state of agriculture is determined, the description of the agricultural park of the Republic of Tatarstan and Russia is presented, performance indicators of agricultural enterprises and directions for further development of the agricultural sector are analyzed.
\end{abstract}

\section{Introduction}

At the present stage of economic development with a sharp increase in the world population, much attention is paid to the intensification of agricultural production.

Due to its geographical features and historical development, Russia, where the Republic of Tatarstan is located, has always been an industrial and agrarian state, focusing on agriculture, which consists of large-scale segments of food production, exchange and consumption. High efficiency of the agricultural sector is a fundamental factor for both the material and social well-being of society, national security of the country.

Development of the agricultural production in Russia depends on its development in each region. In this regard, it is very important to determine the results and development trends in the agricultural sector of the Republic of Tatarstan.

\section{Materials and Methods}

The main information base for the study was data published on the official websites of the Federal State Statistics Service of the Russian Federation and the Republic of Tatarstan, the Ministry of Agriculture and Food of the Republic of Tatarstan, dissertations, monographs and publications.

The study used comparison methods, strategic analysis methods, tabular and graphical methods for presenting data, as well analogies, economic-statistical, monographic, computational, and abstract-logical methods.

\section{Results}

The Republic of Tatarstan is one of the most economically developed regions of Russia consisting of 43 municipal districts and 2 urban districts (Kazan and Naberezhnye Chelny). The Republic of Tatarstan occupies one of the central parts of the large industrial and geographical region of the Russian Federation - the Volga region. The main transport and river highways connecting the northern, southern, eastern and western parts of the country, converge on the territory of the republic. The area is 6783.7 thousand hectares [6].

Each year, the Republic of Tatarstan shows high macroeconomic indicators, which allow it to be among the donor regions of the Russian Federation. Among the regions, Tatarstan is usually in the top ten by gross regional product, and ranks 4 th in the agricultural sector $[3,5,7]$.

In agriculture of the Republic of Tatarstan, there are 139 large enterprises producing dairy products; 10 enterprises processing meat; 3 sugar factories and 6 distilleries. In 2018, the gross regional product amounted to 2115.5 billion rubles, which is $102.8 \%$ of the level of 2017. Figure 1 shows the structure of the gross regional product for 2018.

As can be seen from Figure 1, the share of agriculture in the total structure of the gross regional product of the Republic of Tatarstan was $12.1 \%$. In general, the agricultural sector produced products totaling to 256.1 billion rubles, which is $5.2 \%$ more than in 2017 [8].

The development of agriculture is facilitated by natural and climatic conditions: the territory is characterized by a temperate continental climate, with fairly warm summers and moderately cold winters. July is the warmest month with a temperature of 17-19 degrees, and January is the coldest month with an average temperature of 12-13 degrees below zero. The duration of the period with temperatures above zero is 210 days, the duration of the cold period is 160 days. $470-550 \mathrm{~mm}$ of precipitation falls annually.

The agricultural sector is developing, which is facilitated by climatic conditions, state support, large investment in agriculture, etc. Occupying $2.3 \%$ of agricultural land, the Republic of Tatarstan produces $4.6 \%$ of agricultural products and does not depend on imports. It has a significant potential for increasing agricultural food exports:

* Corresponding author: slonopotam1963@yandex.ru 


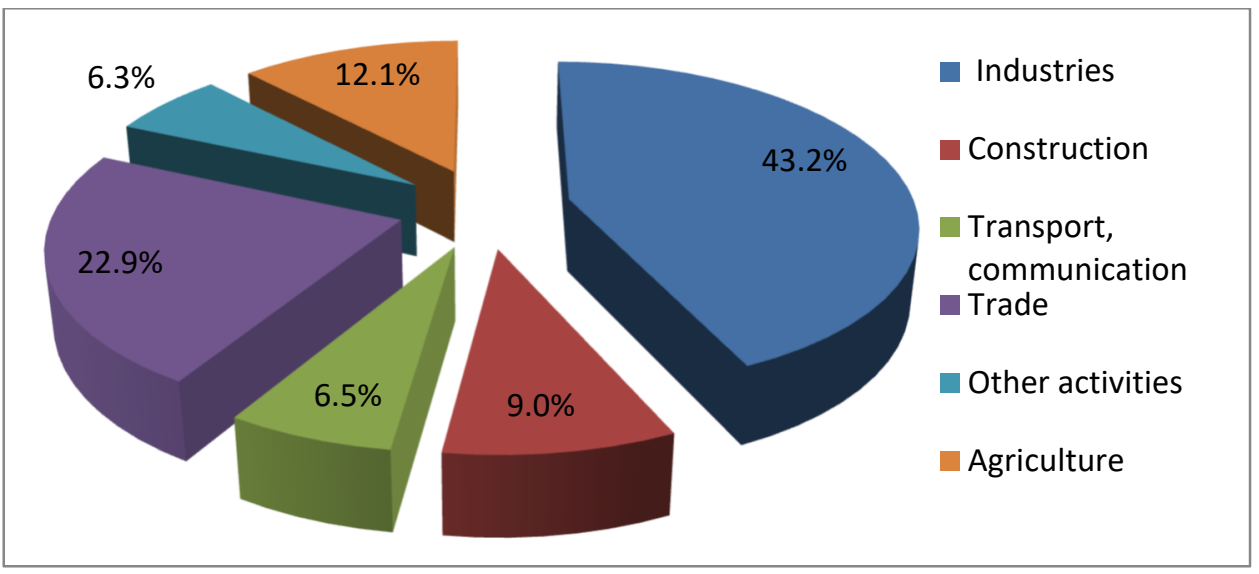

Fig. 1. The share of agriculture in the the gross regional product of the Republic of Tatarstan for 2018

- the volume of exports of agricultural and food products amounted to 176 million dollars, showing an increase of 23 million dollars in relation to 2017;

- the volume of imports of agricultural and food products amounted to 52 million dollars, showing an increase of $\$ 12$ million in relation to 2017 ;

- specific exports (mln. USD / mln. inhabitants) amounted to 45, in Russia - 140;

- specific imports amounted to 13, in Russia -193 [9].
Imports of agricultural products is minimal, especially in comparison with the Russian Federation, the bulk of it is breeding animals (live animals: poultry $30 \%$ and cattle $-60 \%$ ) and drinks. Agriculture is an important element of the economy of Tatarstan. It grows wheat, barley and peas; the most promising processed products are flour, oil, cereals [4].

The dynamics of the gross regional product (GRP) for 2013-2018 is presented in Table 1.

Table 1. Dynamics of the gross regional product of the Republic of Tatarstan for the period 2013-2018 [10]

\begin{tabular}{|l|c|c|c|c|c|c|c|c|}
\hline \multicolumn{1}{|c|}{ Name } & 2013 & 2014 & 2015 & 2016 & 2017 & 2018 & \multicolumn{3}{c|}{ Deviation of 2018 to 2013 } \\
\cline { 5 - 9 } & & & & & & Abs., +/- & Rel., \% \\
\hline Gross regional product, billion rubles & 1551 & 1661 & 1867 & 1937 & 2116 & 2224 & +673 & 143.39 \\
\hline $\begin{array}{l}\text { The share of the agro-industrial complex in } \\
\text { the structure of the GRP of Tatarstan, \% }\end{array}$ & 10.3 & 11.2 & 11.8 & 12 & 12.1 & 12.5 & +2.2 & - \\
\hline
\end{tabular}

Both the dynamics of the gross regional product (+673 billion rubles) and the share of agribusiness in the structure of GRP (+2.2 percentage points) showed positive trends.

Dairy farming is highly developed in the Republic of Tatarstan; milk production exceeds the Russian level 2 times. A similar trend is observed in the cultivation of beets. Table 2 presents the current state of the agroindustrial complex of the Republic of Tatarstan for 2018 by types of products.

The availability of agricultural products in the Republic of Tatarstan is higher than in Russia.

The Republic of Tatarstan supports its agriculture, which is reflected in the technical re-equipment program, due to which the availability of equipment is significantly higher than the average for Russia (table 3) $[1,2]$.

In Tatarstan, there are a large number of different investment parks and "green zones" that have available and fertile land for leasing. A list of such organizations is presented in Table 4.

Zarital Park is an infrastructure complex for farms and entrepreneurs producing meat and dairy production, and vegetables and fruits.

The Baltach Agroindustrial Park is the first Russian project for small and medium-sized businesses working in the halal industry dealing with production and processing of agricultural products grown by private farmers.
Table 2. The current state of agriculture in the Republic of Tatarstan for 2018 [10]

\begin{tabular}{|c|c|c|c|c|}
\hline \multirow{2}{*}{ Name } & \multirow{2}{*}{ 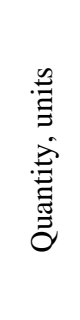 } & \multicolumn{2}{|c|}{$\begin{array}{c}\text { Specific } \\
\text { indicator for } \\
1 \text { million } \\
\text { people, } \%\end{array}$} & \multirow{2}{*}{$\begin{array}{c}\text { Deviation of } \\
\text { the specific } \\
\text { gravity of the } \\
\text { Republic of } \\
\text { Tatarstan to } \\
\text { the Russian } \\
\text { Federation, } \\
+/-\end{array}$} \\
\hline & & 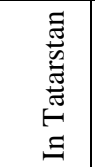 & 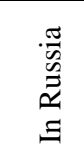 & \\
\hline \multicolumn{5}{|c|}{ Livestock, including: } \\
\hline - bird, million heads & 17.1 & 4.4 & 3.8 & +0.6 \\
\hline $\begin{array}{l}\text { - Cattle, including: } \\
\text { thousand heads }\end{array}$ & 1024 & 262.6 & 127 & +135.6 \\
\hline - cows, thousand heads & 354 & 91 & 55.9 & +35.1 \\
\hline $\begin{array}{l}\text { - sheep and goats, } \\
\text { thousand heads }\end{array}$ & 357 & 91.5 & 167.1 & -75.6 \\
\hline - pigs, thousand heads & 460 & 117.8 & 159.3 & -41.5 \\
\hline \multicolumn{5}{|c|}{ Crop production, including: } \\
\hline - grain, thousand tons & 4868 & 1248.2 & 922.3 & +325.9 \\
\hline - sugar beet, thousand tons & 3100 & 794.9 & 353.8 & +441.1 \\
\hline - potato, thousand tons & 1467 & 376.1 & 201.6 & +174.5 \\
\hline - vegetables, thousand tons & 405 & 103.9 & 111.6 & -7.7 \\
\hline \multicolumn{5}{|c|}{ Basic food products, including: } \\
\hline - milk, thousand tons & 1824 & 467.1 & 212 & +255.1 \\
\hline - egg, mln. & 1188 & 304.5 & 305 & -0.5 \\
\hline $\begin{array}{l}\text { - cattle and poultry for } \\
\text { slaughter, thousand tons }\end{array}$ & 325 & 83.2 & 70.2 & +13 \\
\hline
\end{tabular}


Table 3. Characteristics of the agricultural park of the Republic of Tatarstan and Russia for 2018 [10]

\begin{tabular}{|c|c|c|c|c|}
\hline \multirow[b]{2}{*}{ Name } & \multirow{2}{*}{ 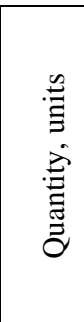 } & \multicolumn{2}{|c|}{$\begin{array}{l}\text { The number of units } \\
\text { of equipment per } \\
1 \text { thousand hectares } \\
\text { of agricultural land }\end{array}$} & \multirow{2}{*}{$\begin{array}{l}\text { Deviation of the } \\
\text { number of machines } \\
\text { in the Republic of } \\
\text { Tatarstan to the } \\
\text { number of machines } \\
\text { in the Russian } \\
\text { Federation, }+/-\end{array}$} \\
\hline & & 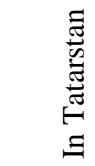 & 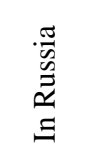 & \\
\hline \begin{tabular}{|l|}
$\begin{array}{l}\text { Combine } \\
\text { harvesters }\end{array}$ \\
\end{tabular} & 3419 & 1.1 & 0.7 & +0.4 \\
\hline Tractors & 13705 & 4.6 & 2.7 & +1.9 \\
\hline \begin{tabular}{|l|} 
Seeders \\
\end{tabular} & 6374 & 2.1 & 1 & +1.1 \\
\hline Cultivators & 5790 & 1.9 & 1.1 & +0.8 \\
\hline \begin{tabular}{|l|} 
Forage \\
harvesters
\end{tabular} & 920 & 0.3 & 0.2 & +0.1 \\
\hline Total & 30208 & 10 & 5.7 & +4.3 \\
\hline
\end{tabular}

Table 4. List of investment parks, providing land for agricultural business in the Republic of Tatarstan as of December 31, 2019 [8]

\begin{tabular}{|l|c|}
\hline \multicolumn{1}{|c|}{ Name } & Free area, ha \\
\hline Industrial park " Technopolis " Himgrad " & 131 \\
\hline $\begin{array}{l}\text { Innovative Industrial Park } \\
\text { " Technopolis " Himgrad " }\end{array}$ & 28.9 \\
\hline Industrial park "Kazan Silicone" & 77,2 \\
\hline Industrial park "KIP Master" & 13.8 \\
\hline Industrial Park " Tyurnasevo " & 6.7 \\
\hline Industrial Park Synergy & 4.3 \\
\hline TOSER "Nizhnekamsk" & 20 \\
\hline Industrial park "Chistopol" & 292 \\
\hline Industrial site "Urusssu" & 19.5 \\
\hline Halal industrial park " Baltacha " & 15.6 \\
\hline JSC "SEZ" Innopolis " & 192.7 \\
\hline Industrial Park SEZ "PPT" Alabuga " & 3867 \\
\hline Industrial Park "Kama Polyany" & 250 \\
\hline Industrial park "M-7" & 39.5 \\
\hline Industrial park " Sokury " & 24 \\
\hline Industrial Park "Tyulyachi" & 33 \\
\hline Industrial Park Chelny & 37 \\
\hline Industrial Park " Yeast " & 19.1 \\
\hline Infrastructural complex Park " Zarital " & 1825 \\
\hline
\end{tabular}

The logistics center "Agromir-Kazan" began to function in 2018 in order to create a wholesale distribution center and retail park. It is located in Pestrechin district. It is expected that the turnover of the project will exceed 700 thousand tons per year.

The agriculture of the Republic of Tatarstan shows positive development trends. Table 5 presents an analysis of the effectiveness of agricultural activities by years.

All performance indicators have positive trends.

The agriculture of the Republic of Tatarstan is a successful and efficient field. To develop it, capital investments are required. With the state support, the projects implemented contributed to greater productivity of agricultural enterprises (Table 6).

At this stage, projects whose implementation is projected in the near future are being implemented (Table 7).
Table 5. Performance indicators of agricultural enterprises in the Republic of Tatarstan for 2016-2018. [10]

\begin{tabular}{|c|c|c|c|c|c|}
\hline \multirow[t]{2}{*}{ Name } & \multirow[t]{2}{*}{2016} & \multirow[t]{2}{*}{2017} & \multirow[t]{2}{*}{2018} & \multicolumn{2}{|c|}{$\begin{array}{l}\text { Deviation in } \\
2018 \text { to } 2016\end{array}$} \\
\hline & & & & Abs., +/- & Rel.\% \\
\hline $\begin{array}{l}\text { The share of } \\
\text { agricultural } \\
\text { entrepreneurs in the } \\
\text { total number of } \\
\text { employed population, } \\
\%\end{array}$ & 8.3 & 8.6 & 8.7 & +0.4 & 104.82 \\
\hline \begin{tabular}{|l|} 
The share of gross \\
agricultural production \\
in the growth of gross \\
regional product, $\%$ \\
\end{tabular} & 11.8 & 12 & 12.1 & +0.3 & 102.54 \\
\hline $\begin{array}{l}\text { The ratio of the wage } \\
\text { growth rate of } \\
\text { agricultural } \\
\text { entrepreneurs to the } \\
\text { wage growth rate in } \\
\text { the region, } \%\end{array}$ & 108,99 & 104.78 & 106.25 & -2.74 & 97.49 \\
\hline \begin{tabular}{|l|} 
Gross income of \\
agricultural enterprises \\
per unit of basic \\
agricultural production \\
and circulating assets, \\
thousand rub. \\
\end{tabular} & 5.81 & 5.84 & 6.07 & +0.26 & 104.48 \\
\hline $\begin{array}{l}\text { The net income of } \\
\text { agricultural } \\
\text { enterprises, mln rub. }\end{array}$ & 7062 & 7563 & 8068 & +1006 & 114.25 \\
\hline $\begin{array}{l}\text { Entrepreneurial } \\
\text { income of agricultural } \\
\text { enterprises, mln rub. }\end{array}$ & 6891 & 7303 & 7669 & +778 & 111.29 \\
\hline
\end{tabular}

Table 6. Implementation of projects for the development of agricultural enterprises of the Republic of Tatarstan for 20152018. [9]

\begin{tabular}{|l|c|c|c|}
\hline \multicolumn{1}{|c|}{ Name } & $\begin{array}{c}\text { The volume } \\
\text { of } \\
\text { investments, } \\
\text { mln rub. }\end{array}$ & $\begin{array}{c}\text { Number } \\
\text { of } \\
\text { objects, } \\
\text { units }\end{array}$ & $\begin{array}{c}\text { Capacity } \\
\text { input }\end{array}$ \\
\hline $\begin{array}{l}\text { Construction and } \\
\text { modernization of dairy } \\
\text { facilities }\end{array}$ & 3227.3 & 27 & $\begin{array}{c}11500 \\
\text { heads }\end{array}$ \\
\hline $\begin{array}{l}\text { Vegetable and potato } \\
\text { ttorages }\end{array}$ & 127.6 & 2 & 8 tons \\
\hline Greenhouse facilities & 389 & 2 & $2.1 \mathrm{ha}$ \\
\hline Overhaul of cowsheds & 1681.6 & 352 & - \\
\hline $\begin{array}{l}\text { Construction of silo- } \\
\text { silage trenches }\end{array}$ & 204.5 & 129 & - \\
\hline $\begin{array}{l}\text { Overhaul of vegetable } \\
\text { and potato storages }\end{array}$ & 166.7 & 28 & - \\
\hline Overhaul of fleets & 33,4 & 14 & - \\
\hline $\begin{array}{l}\text { Construction of access } \\
\text { roads to family farms and } \\
\text { livestock complexes }\end{array}$ & 200 & 32 & $25.4 \mathrm{~km}$ \\
\hline Other & 133.9 & 93 & - \\
\hline Total & 6164 & - & - \\
\hline
\end{tabular}

Capital investment contributes to the development of agriculture. All measures for the development of agricultural entrepreneurship are implemented within the state program "Development of agriculture and regulation of agricultural products, raw materials and food 
markets in the Republic of Tatarstan for 2013-2021", which includes the achievement of the following goals:

- increasing the competitiveness of agricultural products in the domestic and foreign markets on the basis of innovative development of the agricultural sector;
- increasing the financial stability of agricultural producers;

- increasing the efficiency of land management, greening of production;

- sustainable development of rural areas.

Table 7. Projects for the development of agricultural enterprises of the Republic of Tatarstan [9]

\begin{tabular}{|l|l|c|c|c|}
\hline \multicolumn{1}{|c|}{ Company name } & \multicolumn{1}{|c|}{ Type of the project } & $\begin{array}{c}\text { Project } \\
\text { Duration }\end{array}$ & $\begin{array}{c}\text { The volume of } \\
\text { investments, } \\
\text { mln rub. }\end{array}$ & Capacity input \\
\hline LLC Chelny Broiler & Poultry slaughtering enterprise & $2017-2019$ & 4254.4 & 10500 heads/h \\
\hline LLC " Aznakay " & $\begin{array}{l}\text { Construction of a livestock facility for 2000 } \\
\text { milk cows }\end{array}$ & $2018-2019$ & 1007 & 12,000 tons per year \\
\hline APK Food Program LLC & Construction of a farm for growing young cattle & $2017-2019$ & 1250 & 10,000 heads \\
\hline Phoenix LLC & Construction of a pig breeding facility & $2017-2019$ & 1087 & 65,000 heads \\
\hline LLC " AydzhiesAgro " & Construction of a champignon facility & $2018-2019$ & 1067 & 5600 tons per year \\
\hline LLC TK Maysky & Construction of block greenhouses & $2018-2019$ & 921 & 5.14 ha \\
\hline LLC "Biosphere Fish" & Construction of a sterlet rearing facility & $2017-2019$ & 625 & 5 mln in year \\
\hline LLC " Miramol " & Construction of a dairy farm & $2017-2022$ & 2200 & 4800 heads of dairy herd \\
\hline $\begin{array}{l}\text { PC “ Agrosila . Chelny-IPK } \\
\text { Chicken Meat Processing Plant }\end{array}$ & $2018-2020$ & 3100 & 144 tons per day \\
\hline Farm " Ramaevskoe " & Duck production enterprise & $2018-2020$ & 250 & $\begin{array}{c}2250000 \text { pcs. ducks per } \\
\text { year }\end{array}$ \\
\hline
\end{tabular}

Within this program, the volume of financial resources allocated will amount to $182,172.015$ million rubles, including from the federal budget, the budget of the Republic of Tatarstan and extrabudgetary funds (Table 8).

Table 8. The volume of resource support for implementing the program by years

\begin{tabular}{|c|c|c|c|}
\hline \multirow{2}{*}{ Year } & \multicolumn{3}{|c|}{ Volume of investment, million rubles } \\
\cline { 2 - 4 } & $\begin{array}{c}\text { from the budget } \\
\text { of the Republic } \\
\text { of Tatarstan }\end{array}$ & $\begin{array}{c}\text { from the } \\
\text { federal budget }\end{array}$ & $\begin{array}{c}\text { from } \\
\text { extrabudgetary } \\
\text { sources }\end{array}$ \\
\hline 2013 & 7821.363 & 11078.526 & 3.437 \\
\hline 2014 & 10387.324 & 9851.733 & 966.204 \\
\hline 2015 & 14863.995 & 11989.745 & 205.3 \\
\hline 2016 & 11862.463 & 10175.709 & 175.589 \\
\hline 2017 & 16038.935 & 8277.268 & 361.309 \\
\hline 2018 & 11172.012 & 6619.157 & 511.486 \\
\hline 2019 & 8237.355 & 5881.844 & 422.052 \\
\hline 2020 & 8237.355 & 5881.844 & 411.342 \\
\hline 2021 & 8251.363 & 8971.899 & 411.342 \\
\hline Total & 96886.172 & 81817.782 & 3468.061 \\
\hline
\end{tabular}

\section{Conclusion}

Today, the policy of the Republic of Tatarstan is aimed at the developing the following promising areas:

- production of seeds of all types of crop products, especially those that are actively zoned in the Republic of Tatarstan;

- construction of processing complexes and factories for the production of such types of products as juices, compotes, canned fish, desserts obtained from various types of berries and fruits; mushrooms; fermented, pickled and salted concentrates;

- further development of commercial fish farms of intensive type with the development of recycling water supply systems for growing valuable fish species, especially sturgeon;
- further construction and reconstruction of enterprises for the production of various dairy products based on the processing of milk from various animals;

- construction of centers for processing agricultural crop products in order to obtain various food additives;

- active construction of logistics centers for the purchase and sale of agricultural products.

For the implementation and development of all of the above areas in the Republic of Tatarstan, there are the following reserves:

- a large arable land giving high yields;

- a large percentage of imports (especially in large cities);

- the need to increase the provision of the republic with its own ecological agricultural products;

- availability of a sufficient amount of various types of manufactured products ready for processing.

Thus, we can note that agriculture in the Republic of Tatarstan has a vector of development and an increase in the efficiency of activities, since the calculation of the main indicators characterizing the performance of entrepreneurs has revealed a positive trend for the periods under consideration. The increase in the share of employed agricultural entrepreneurs in the total employed population and the share of the gross agricultural product in the growth of the gross regional product, as well as an increase in capital productivity, net and entrepreneurial income of agricultural enterprises, indicate the progress in the development of agricultural entrepreneurship in Tatarstan.

Today, the Republic of Tatarstan is developing its agriculture in the improved conditions of production activities, which include: almost ideal natural and climatic conditions, close to the optimal ones of Krasnodar; the location of agricultural enterprises in one of the developed regions located in the geographical center of Russia, which directly affects the effectiveness of all agricultural production; constant effective 
measures carried out by the authorities of the republic, contributing to the further steady and accelerated development of the entire agricultural complex of the republic.

\section{References}

1. N.M. Asadullin, L.N. Asadullin, M.M. Khismatullin, The concept of efficient use of resources during the technical operation of agricultural machinery, Bull. of Kazan SAU, 3(21), 17-19 (2011)

2. N.M. Asadullin, Current problems of the use of trucks in agriculture, Bull. of Kazan SAU, 4-2(56), 44-48 (2019)

3. I.G. Gainutdinov, F.N. Mukhametgaliev, D.F. Khafizov et al., Issues of the development of small forms of management and cooperation in rural areas, Bull. of Kazan SAU, 1(52), 138-144 (2019)

4. L.V. Mikhailova, D.R. Nigmatzyanova, Management of diversification processes in the agricultural sector based on the development of small agribusiness, Vector of Econ., 10(28), 108 (2018)

5. F.N. Mukhametgaliev, L.F. Sitdikova, F.F. Mukhametgalieva et al., Trends in the formation of modern agri-food policy of Russia, Probl. of forecast., 2(173), 73-77 (2019)

6. L.F. Sitdikova, D.I. Fayzrakhmanov, F.N. Mukhametgaliev, Strategic objectives of agricultural development in the Republic of Tatarstan, Herald of the Kazan State Agrar. Univer., 10(1(35)), 45-50 (2015)

7. D.I. Fayzrakhmanov, L.F. Khaziev, Risks associated with innovation and investment in the agricultural sector, Bull. of Kazan SAU, 3(41), 107-113 (2016)

8. The agro-industrial complex of the Republic of Tatarstan, Retrieved from: http://agro.tatarstan.ru/eng/file/pub/pub_209266

9. The Ministry of Agriculture and Food of the Republic of Tatarstan, Retrieved from: http://agro.tatarstan.ru/rus/plans.

10. Territorial authority of the Federal State Statistics Service for the Republic of Tatarstan, Retrieved from: http://tatstat.gks.ru 